\title{
ANALISIS PERBANDINGAN KUAT TEKAN MORTAR DARI MATERIAL PASIR PUTIH DAN PASIR BIASA SUNGAI MASAMBA
}

\author{
Lusman Sulaiman $^{1)}$, Nurhidayah ${ }^{2)}$ \\ 1) Dosen Program Studi Teknik Sipil, Universitas Andi Djemma, Palopo \\ ${ }^{2)}$ Dosen Program Studi Teknik Sipil, Universitas Andi Djemma, Palopo \\ ${ }^{1)}$ sulaimanlusman@gmail.com \\ 2) hidayah03@gmail.com
}

\begin{abstract}
Abstrak
Sumber utama pasir berasal dari sungai atau daerah pantai yang memiliki karakteristik yang berbedabeda, baik kekuatan tekan maupun tampak warna fisiknya. Perlu diketahui perbandingan sifat kekuatan material mortar dengan menggunakan campuran pasir putih (CPP) dan biasa (CPB) sungai masamba dan korelasi keduanya. Penelitian ini dilakukan dengan metode eksperimen laboratorium pada 72 benda uji berbentuk kubus dengan ukuran $15 \times 10 \times 15 \mathrm{~cm}$ yang dibentuk secara manual sesuai proses pembuatannya di lapangan. Benda uji diletakkan di area terbuka untuk proses pengeringan selama variasi waktu 7, 14, 21, 28 hari. Tiga kategori campuran benda uji dibuat yaitu 1PC : 3PS (A), 1PC: 4PS (B), dan 1PC : 5PS (C) pasir untuk dua jenis pasir dengan Faktor Air Semen (FAS) 0.45. Nilai rata-rata hasil pengujian terdiri dari 3 buah sampel uji dari pengujian menggunakan mesin uji kuat tekan. Mutu rencana penelitian ini merujuk pada SNI 03-0349-1989 tentang kategori bata beton untuk pasangan dinding. Hasil pengujian kuat tekan memperlihatkan bahwa kuat tekan bata beton untuk material CPP mencapai maksimum 28 hari pada campuran A dengan nilai sebesar $151.77 \mathrm{~kg} / \mathrm{cm}^{2}$ sedangkan material CPB pada campuran A dengan nilai $161.10 \mathrm{~kg} / \mathrm{cm}^{2}$. Korelasi kedua material CPP dan CPB menggambarkan relasi tinggi sebesar $\mathrm{R}^{2}=0.9738$ pada campuran $\mathrm{A}$.
\end{abstract}

Kata Kunci: pasir putih, pasir biasa, mortar, kuat tekan

\section{PENDAHULUAN}

Seiring meningkatnya permintaan akan kebutuhan rumah untuk menunjang keberlangsungan kehidupan manusia dari hari kehari, material untuk memproduksi bata beton yang bahan dasar agregat pasir semakin meningkat. Peningkatan jumlah ini diperkirakan akan terus mengalami kenaikan di tahun-tahun berikutnya sehingga upaya peningkatan kualitas hasil produk bata beton perlu dilakukan dengan cara mengevaluasi kekuatan dan karakteristik bahan yang digunakan.

Beberapa Negara dibelahan dunia pada tahun 2003 menunjukkan tingkat konsumsi agregat pasir perkapita yang dapat dilihat pada Gambar 1. Hal ini merepresentasikan total penggunaan agregat pasir tidak hanya pada bata beton tetapi juga produksi beton. Sehingga implikasi yang terjadi atas pemanfaatan agregat pasir ini dapat berupa terbatasnya ketersediaan dari sumber alamiahnya.

Seperti diketahui bahwa PP (Gambar 2a) banyak dijumpai pada daerah muara sungai yang berbatasan langsung dengan daerah pantai yang jumlahnya berlimpah ruah, akan tetapi pengolahan dan produksinya masih sangat jarang digunakan sebagai bagian dari konstruksi bangunan. Hal berbeda, PB (Gambar 2b) menjadi kebutuhan utama dalam konstruksi bangunan karena diyakini memiliki kekuatan lebih tinggi dari PP. Namun pengujian secara eksperimen belum membuktikan dan masih sangat sedikit hal tersebut dilakukan. Sehingga, kedua material ini sangat perlu untuk dilakukan pengujian menyeluruh atau yang dianggap telah memenuhi syarat dalam campuran mortar baik dari sisi karakterisrik fisik maupun mekaniknya.

Di Indonesia, produksi bata beton yang menggunakan PB dari waktu ke waktu cukup terlihat mengalami peningkatan sehingga berdampak pada penurunan jumlah 
PB dari sumber-sumber alamiahnya. Ditambah proses pengambilan PB juga dapat diperoleh dari luar lokasi penambangan yang menjadikan harga lebih mahal (Maulana, 2012). Selain itu, dampak negatif penggunaan material PB yang hanya mengandalkan pasir tertentu dapat meningkatkan tingkat kerusakan ekosistem disekitar sungai. Oleh karena itu, perlu dilakukan manajemen dan kebijakan terhadap pemanfaatan pasir alam secara proporsional dan komprehensip (Dyahwanti, 2007 \& Yudhistira et al., 2012). Salah satu yang dapat dimanfaatkan potensinya adalah keberadaan material PP yang tersebar di berbagai tempat seperti daerah aliran sungai hingga pesisir pantai.

Oleh karena itu, penelitian ini dimaksudkan untuk menguji dan mengevaluasi kekuatan agregat PP dari sisi beban tekan dari umur 7 hari hingga mencapai maksimum perawatan 28 hari. Selanjutnya hasil pengujian akan diperlihat secara detail untuk memberikan rekomendasi kelayakan dalam pemanfaatannya.

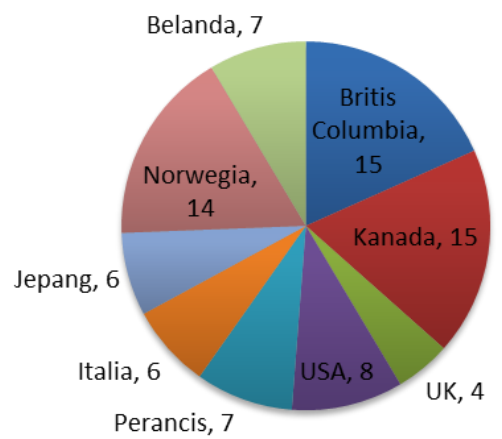

Gambar 1. Tingkat Konsumsi Agregat Pasir Perkapita Pertahun (Ton)
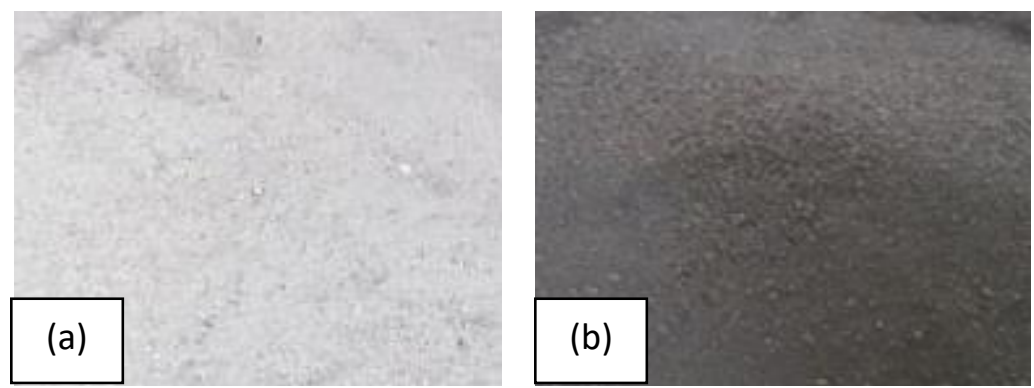

Gambar 2. Agregat (a) PP dan (b) PB

\section{Bata Beton}

Pada umumnya, bata beton yang digunakan sebagai dinding memiliki komposisi serupa dengan campuran mortar beton yaitu semen, pasir dan air. Bata beton dibagi menjadi dua jenis yaitu pertama bata beton pejal adalah bata yang memiliki volume pejal (padat) sebesar $75 \%$ dari volume bata seluruhnya dan kedua adalah bata beton berlubang (berongga) adalah bata memiliki volume lubang lebih dari $25 \%$ dari volume bata seluruhnya (SNI 03-0349-1989).

Syarat-syarat fisis dan mutu bata beton pejal berdasarkan SNI-03-049-1989 dapat dilihat pada Tabel 1. 
Tabel 1. Syarat Fisis Dan Mutu Bata Beton Pejal

\begin{tabular}{lccccc}
\hline \multirow{2}{*}{ Jenis Pengujian } & Satuan & \multicolumn{5}{c}{ Tingkat mutu bata beton pejal } \\
\cline { 3 - 6 } & & I & II & III & IV \\
\hline $\begin{array}{l}\text { Kuat tekan bruto } \\
\text { rata-rata min }\end{array}$ & $\mathrm{Kg} / \mathrm{cm}^{2}$ & 100 & 70 & 40 & 25 \\
\hline $\begin{array}{l}\text { Kuat tekan bruto } \\
\text { masing-masing } \\
\text { benda uji min }\end{array}$ & $\mathrm{Kg} / \mathrm{cm}^{2}$ & 90 & 65 & 35 & 21 \\
\hline $\begin{array}{l}\text { Penyerapan air } \\
\text { rata-rata maks. }\end{array}$ & $\%$ & 23 & 35 & - & - \\
\hline
\end{tabular}

Untuk pemanfaatanya, bata dikategorikan kedalam empat mutu yaitu mutu I digunakan sebagai bagian struktur yang dapat memikul beban serta tidak terlindungi terhadap lingkungan luar, mutu II diaplikasikan sebagai material penahan beban dan terlindungi dari kondisi lingkungan luar seperti panas, mutu III digunakan hanya untuk bagian konstruksi nonstruktural yang tidak memikul beban dan tidak dilindungi dengan plesteran dan mutu IV diperuntukan untuk bagian struktur bangunan yang tidak menerima beban luar.

\section{Karakteristik Pasir Putih dan Pasir Biasa}

Agregat pasir terbentuk dari hasil erosi atau pelapukan batuan hingga menjadi butiran-butiran kecil berdiameter lebih kecil dari $4.75 \mathrm{~mm}$. pelapukan ini terjadi secara alamiah di daratan oleh air yang terjadi secara terus menerus hingga terbawa ke aliran sungai dan membentuk sedimen berupa material pasir serta dapat mencapai lautan. Kebanyakan agregat pasir alam ini memiliki berat jenis antara $1500-1700 \mathrm{~kg} / \mathrm{m} 3$ dan berat jenis padat dapat mencapai $2000 \mathrm{~kg} / \mathrm{m} 3$.

Umumnya, material ini memiliki jenis yang beberbeda tergantung dari mineral yang dikandungnya. Dalam hal ini, agregat PP pada dasarnya memiliki kandungan mineral kalsium karbonat $(\mathrm{CaCO} 3)$ dengan tingkat kemurnian tinggi sehingga menjadikan warna fisiknya putih. Menurut Silvia et al., (2018) kandungan mineral Ca pada pasir pantai rata-rata sekitar 93\% dari total komposisi mineral yang terkandung pada material PP. Sementara agregat PB yang biasanya dipakai pada pembuatan konstruksi banguana seperti pengecoran balok, kolom, plesteran dan dinding bata beton memiliki warna kehitaman. Hal tersebut berdasarkan penelitian yang dilakukan oleh Saniah. et al., (2015) mengungkapkan bahwa dominasi kandungan feroksida (Fe2O4) menjadikan material PB berwarna hitam.

Tak kalah penting dalam penggunaan agregat pasir dalam pembuatan campuran mortar adalah gradasi atau ukuran partikel pasir yang diukur berdasarkan Fine Modulus (FM) yang dapat mempengaruhi kekuatan bahan maortar. Tabel 2 memperlihatkan kategori ukuran pasir berdasarkan standar BS 882:1992 (Davies et al., 2016). Pengaruh gradasi pasir sangat mempengaruhi kuat tekan baik mortar maupun beton. Menurut Li (2011) dalam bukunya memberikan penjelasan bahwa maksimum kekuatan tekan akan dicapai dengan menggunakan 35\% dari total volume campuran sebesar 36 Mpa pada lolos saringan $0.6 \mathrm{~mm}$. 
Tabel 2. Tingkat Kehalusan Pasir

\begin{tabular}{lc}
\hline \multicolumn{1}{c}{ FM } & Kehalusan pasir \\
\hline$<1,0$ & Sangat halus \\
\hline $1,0-2,0$ & Halus \\
\hline $2,0-2,9$ & Medium \\
\hline $2,9-3,5$ & Kasar \\
\hline$>3,5$ & Sangat kasar \\
\hline
\end{tabular}

\section{METODOLOGI PENELITIAN}

\section{Semen Portland}

Jenis semen yang digunakan dalam penelitian ini adalah semen tipe I yang komposisinya serupa dengan type I-ASTM. Tabel 3 memperlihatkan komposisi kimia yang ada pada semen portland secara umum.

Tabel 3. Komposisi kimia semen portland

\begin{tabular}{lclc}
\hline \multicolumn{1}{c}{ Oksida } & Notasi & \multicolumn{1}{c}{ Nama } & Persen berat \\
\hline $\mathrm{CaO}$ & $\mathrm{C}$ & Kapur & 64,67 \\
\hline $\mathrm{SiO}_{2}$ & $\mathrm{~S}$ & Silica & 21,03 \\
\hline $\mathrm{Al}_{2} \mathrm{O}_{3}$ & $\mathrm{~A}$ & Alumina & 6,16 \\
\hline $\mathrm{Fe}_{2} \mathrm{O}_{3}$ & $\mathrm{~F}$ & Oksida besi & 2,58 \\
\hline $\mathrm{MgO}$ & $\mathrm{M}$ & Magnesium & 2,62 \\
\hline $\mathrm{K}_{2} \mathrm{O}$ & $\mathrm{K}$ & Alkalis & 0,61 \\
\hline $\mathrm{Na}_{2} \mathrm{O}$ & $\mathrm{N}$ & Alkalis & 0,34 \\
\hline $\mathrm{SO}_{3}$ & $\underline{\mathrm{S}}$ & Sulfat & 2,03 \\
\hline
\end{tabular}

Agregat Pasir Putih dan Pasir Biasa

Material utama yang digunakan pada penelitian ini adalah agregat PP dan PB yang diperoleh dari sungai masamba kab. Luwu Utara. Lokasi pengambilan kedua material ini dapat dilihat pada Gambar 3. Titik pengambilan agregat PP berada pada daerah bendungan baliase dan agregat PB berada pada titik yang berdekatan muara sungai pada daerah pesisir pantai.

Karakteristik fisik yang paling menonjol dari material PP dan PB adalah tekstur dan warna dimana tekstur PP lebih halus dibandingkan PB dan PP memiliki warna putih sedangkan PB kehitaman. Dari hasil analisis saringan yang menggunakan beberapa nomor saringan (No.4-No.100), Gradasi kedua material ini terlihat cukup berbeda seperti pada Gambar 4.

Gambar 4 memperlihatkan besarnya persen lolos agregat PP pada saringan no. 4 hingga no. 30 dibandingkan agregat PB. Hal ini menunjukkan bahwa ukuran butiran agregat PP memiliki diameter lebih kecil dan halus dibandingkan dengan agregat PB. Ditambah hasil perhitungan modulus kehalusan (FM) PP dan PB diperoleh berturutturut sebesar 2.19 dan 2.54. Hasil perhitungan tersebut dapat dilihat secara detail pada Tabel 4. 


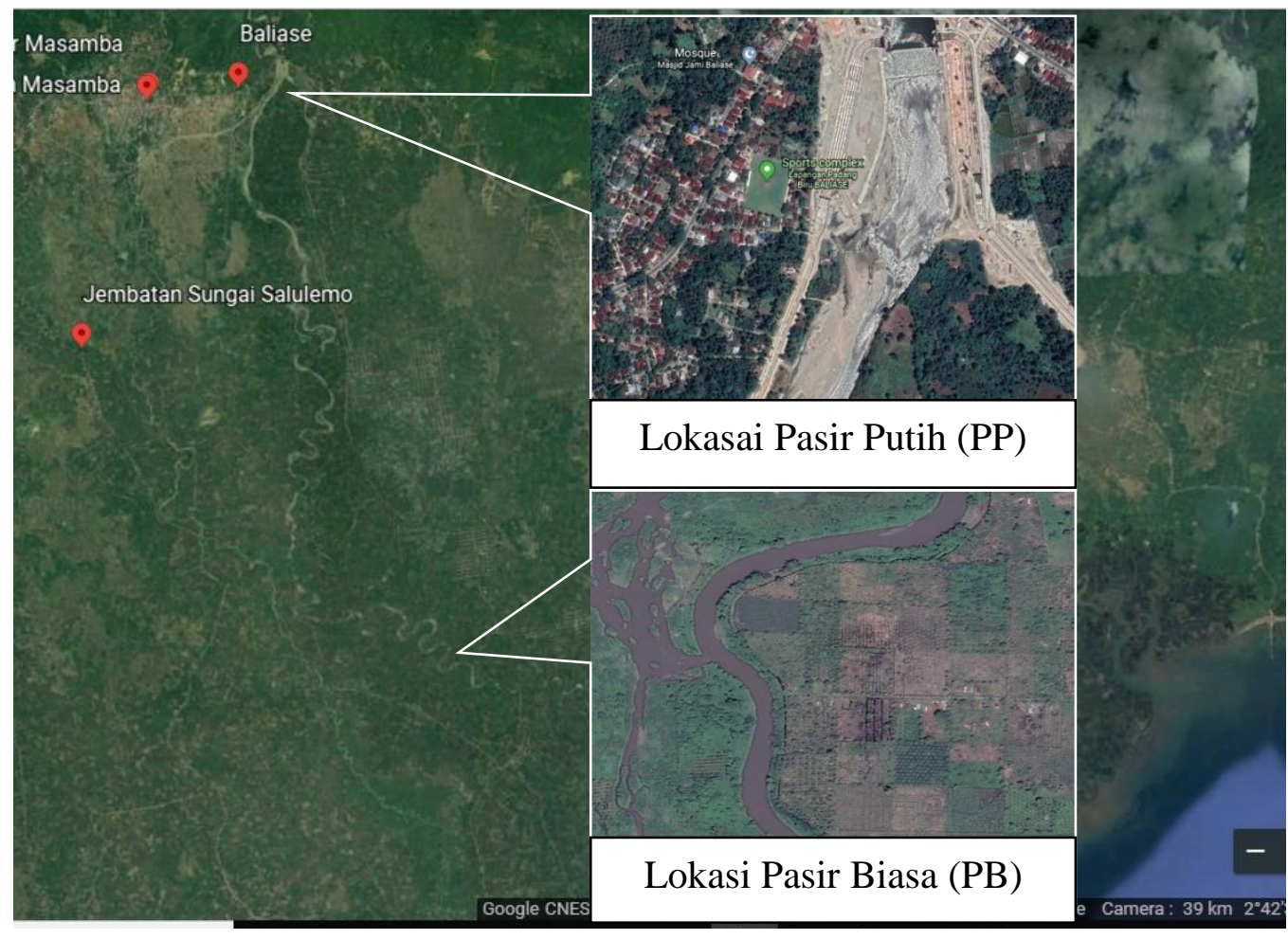

Gambar 3. Lokasi Pengambilan Agregat PP \& PB

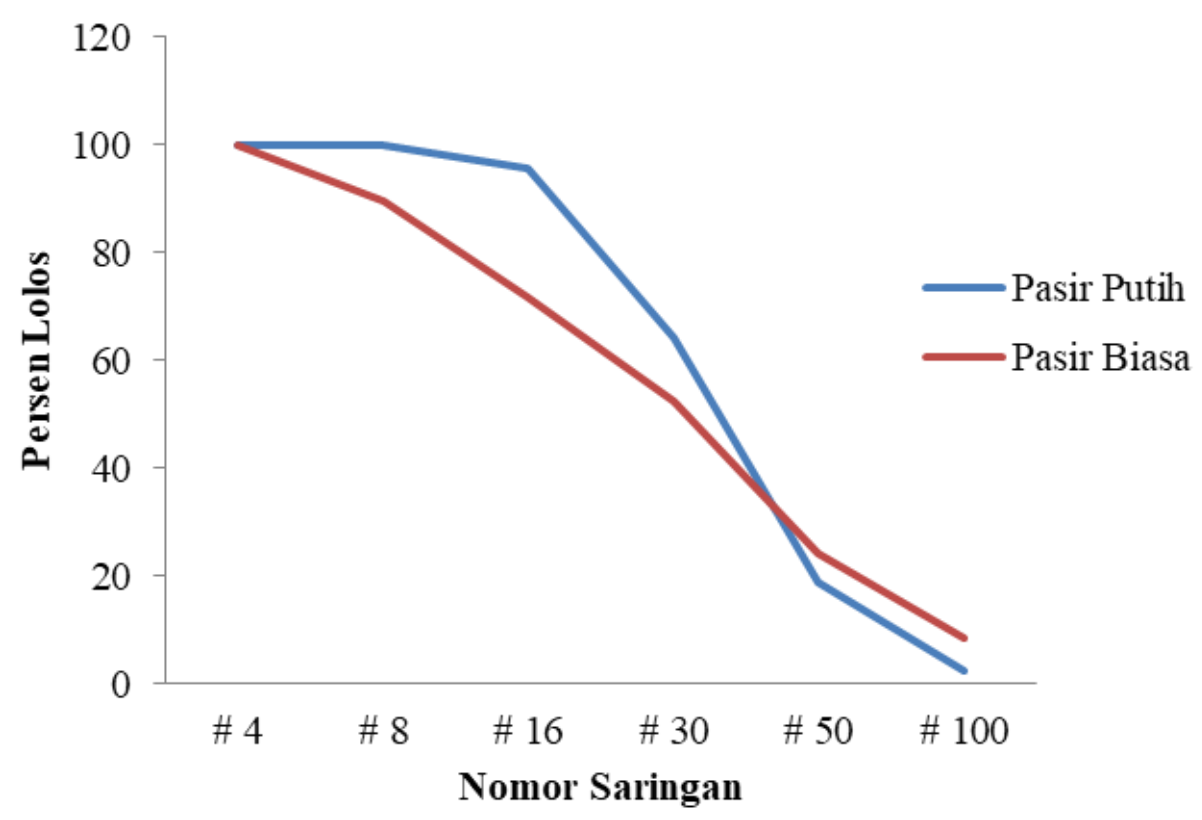

Gambar 4. Gradasi PP dan PB 
Tabel 4. Modulus kehalusan pasir PP dan PB

\begin{tabular}{|c|c|c|c|c|c|c|}
\hline \multirow{2}{*}{$\begin{array}{c}\text { Nomor } \\
\text { saringan }\end{array}$} & \multirow{2}{*}{$\begin{array}{c}\begin{array}{c}\text { Berat } \\
\text { tertahan }\end{array} \\
\mathrm{PP} \\
\end{array}$} & \multirow{2}{*}{$\begin{array}{c}\begin{array}{c}\text { Berat } \\
\text { tertahan }\end{array} \\
\mathrm{PB}\end{array}$} & \multirow{2}{*}{$\begin{array}{c}\begin{array}{c}\text { Berat } \\
\text { tertahan }\end{array} \\
\mathrm{PP} \\
\end{array}$} & \multirow{2}{*}{$\begin{array}{c}\begin{array}{c}\text { Berat } \\
\text { tertahan }\end{array} \\
\mathrm{PB} \\
\end{array}$} & \multicolumn{2}{|c|}{$\begin{array}{c}\text { Komulatif } \\
\text { tertahan }\end{array}$} \\
\hline & & & & & $\mathrm{PP}$ & PB \\
\hline $\mathrm{mm}$ & \multicolumn{2}{|c|}{ gram } & \multicolumn{2}{|c|}{$\%$} & \multicolumn{2}{|c|}{$\%$} \\
\hline$\# 4(4,75 \mathrm{~mm})$ & 0,0 & 3,3 & 0,0 & 0,2 & 0,0 & 0,2 \\
\hline$\# 8(9,50 \mathrm{~mm})$ & 3,3 & 150,9 & 0,2 & 10,1 & 0,2 & 10,3 \\
\hline$\# 16(1,18 \mathrm{~mm})$ & 62,0 & 270,3 & 4,1 & 18,0 & 4,4 & 28,3 \\
\hline$\# 30(0,60 \mathrm{~mm})$ & 473,2 & 292,3 & 31,4 & 19,5 & 35,7 & 47,8 \\
\hline$\# 50(0,275 \mathrm{~mm})$ & 684,2 & 421,2 & 45,6 & 28,1 & 81,3 & 75,9 \\
\hline$\# 100(0,149 \mathrm{~mm})$ & 248,2 & 236,8 & 16,5 & 15,8 & 97,9 & 91,7 \\
\hline Jumlah & 32,0 & 125,2 & 2,1 & 8,3 & & \\
\hline Sisa & 1500 & 1500 & 4792 & & 219,5 & 254,1 \\
\hline FM & \multicolumn{3}{|c|}{$\frac{\text { Jumlah komulatif tertahan }}{100}$} & $=$ & 2,19 & 2,54 \\
\hline
\end{tabular}

\section{Desain dan Pengujian Benda Uji}

a) Desain Campuran Benda Uji

Proses desain campuran dalam pembuatan benda uji mengacu pada SNI 03-68252002 dan kondisi di lapangan. Material yang digunakan dalam perencanaan desain campuran bata beton adalah berdasarkan sifat-sifat hasil pengujian yang telah dilakukan dengan benda uji kubus dengan ukuran $15 \times 10 \times 15 \mathrm{~mm}$ dan faktor air semen rencana sebesar 0.45 .

Dua jenis campuran yang berbeda disiapkan yaitu (1) bata beton dari campuran semen portland, pasir putih, dan air dengan simbol CPP, (2) bata beton dari campuran semen portland, pasir biasa, dan air dengan simbol CPB. Masing-masing jenis campuran dibuat dengan perbandingan 1PC : 3PS (A), 1PC : 4 PS (B) dan 1PC : 5PS (C) yang kemudian dilakukan perawatan selama 7, 14, 21, dan 28 hari. Perlakuan yang diberikan dari total 72 benda uji selama masa perawatan tidak lepas dari prosesnya sesuai dengan yang ada di lapangan. Detail benda uji dapat diperlihatkan pada Tabel 5.

Tabel 5. Detail penelitian

\begin{tabular}{|c|c|c|c|c|c|c|c|c|}
\hline \multirow{2}{*}{$\begin{array}{c}\text { Jenis } \\
\text { Percobaan }\end{array}$} & \multicolumn{2}{|c|}{ Perbandingan } & \multicolumn{4}{|c|}{$\begin{array}{c}\text { Umur perawatan } \\
\text { (hari) }\end{array}$} & \multirow{2}{*}{ FAS } & \multirow{2}{*}{$\begin{array}{l}\text { Jumlah } \\
\text { benda uji }\end{array}$} \\
\hline & $\begin{array}{c}\text { Semen } \\
(\mathrm{PC})\end{array}$ & $\begin{array}{c}\text { Pasir } \\
\text { (PS) }\end{array}$ & 7 & 14 & 21 & 28 & & \\
\hline \multirow{3}{*}{ CPP } & 1 & 3 & 3 & 3 & 3 & 3 & \multirow{7}{*}{0,45} & 12 \\
\hline & 1 & 4 & 3 & 3 & 3 & 3 & & 12 \\
\hline & 1 & 5 & 3 & 3 & 3 & 3 & & 12 \\
\hline \multirow{3}{*}{$\mathrm{CPB}$} & 1 & 3 & 3 & 3 & 3 & 3 & & 12 \\
\hline & 1 & 4 & 3 & 3 & 3 & 3 & & 12 \\
\hline & 1 & 5 & 3 & 3 & 3 & 3 & & 12 \\
\hline \multicolumn{7}{|c|}{ Total } & & 72 \\
\hline
\end{tabular}

b) Rancangan Pengujian

Pengujian kuat tekan ( $\left.f^{\prime} c\right)$ benda uji silinder beton dilakukan dengan menggunakan alat compression test atau alat uji kuat tekan dan detail spesimen uji seperti terlihat pada Gambar 5. Kapasitas alat yang akan digunakan pada penelitian ini dapat mencapai beban tekan hingga $50 \mathrm{MPa}$ dan kecepatan secara berkesinambungan rata-rata sebesar 0.14 sampai $0.34 \mathrm{MPa}$ /detik. Setiap hasil pengujian, tiga spesimen 
diuji untuk mendapatkan suatu nilai rata-rata. Keseluruhan prosedur pengujian mengacu pada SNI 1947:2011.

Besarnya kuat tekan $(\sigma)$ yang terjadi pada setiap spesimen uji, maka digunakan persamaan matematis dimana nilai kuat tekan berbanding dengan beban $(\mathrm{P})$ dibagi luas penampang (A) seperti pada pers. 1.

$\sigma=\frac{P}{A}$

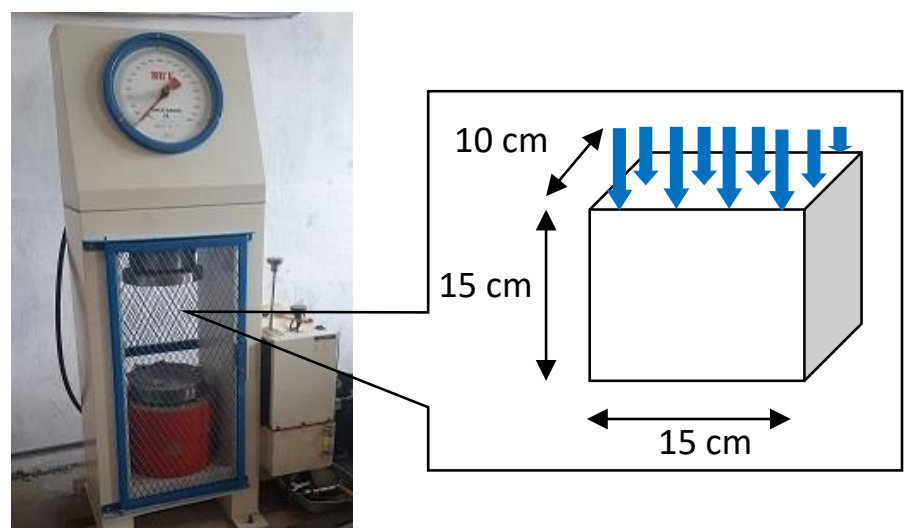

Gambar 5. Mesin Uji Kuat Tekan dan Spesimen Uji

\section{HASIL DAN PEMBAHASAN}

\section{Hasil pengujian kuat tekan}

Pengujian terhdap 72 sampel ujin yang terdiri dari 36 CPP dan 36 CPB dapat diperlihatkan pada Tabel 5. Dua jenis percobaan ini terdiri dari variasi campuran dan umur perawatan dimana CPP dan CPB masing-masing terdiri dari perbandingan 1PC:3PS, 1PC:4PC, dan 1PC:5PC. Tiap variasi campuran terdiri atas tiga benda uji yang kemudan hasilnya diperoleh dari perhitungan rerata sampel uji.

Dari Tabel 6 tersebut, hasil pengujian memperlihatkan tren terjadinya penurunan nilai kuat tekan seiring semakin bertambahnya jumlah variasi campuran pasir maupun lamanya perawatan benda uji. Selain itu, nilai kekuatan CPP memiliki kuat tekan lebih besar dibandingkan dengan CPB.

Tabel 6. Hasil pengujian kuat tekan

\begin{tabular}{cccccc}
\hline \multirow{2}{*}{$\begin{array}{c}\text { Jenis } \\
\text { Perobaan }\end{array}$} & $\begin{array}{c}\text { Variasi } \\
\text { Campuran }\end{array}$ & $\mathbf{7 ~ h a r i}$ & $\mathbf{1 4}$ hari & $\mathbf{2 1}$ hari & $\mathbf{2 8}$ hari \\
\hline \multirow{3}{*}{ CPP } & 1PC:3PS & 117,79 & 137,05 & 138,18 & 151,77 \\
\cline { 2 - 6 } & 1PC:4PS & 78,15 & 89,48 & 90,61 & 99,67 \\
\cline { 2 - 6 } & 1PC:5PS & 64,56 & 66,83 & 70,22 & 77,02 \\
\hline \multirow{3}{*}{ CPB } & 1PC:3PS & 121,19 & 139,31 & 142,71 & 163,1 \\
\cline { 2 - 6 } & 1PC:4PS & 80,42 & 90,61 & 92,88 & 100,8 \\
\cline { 2 - 6 } & 1PC:5PS & 64,56 & 73,62 & 75,89 & 81,55 \\
\hline
\end{tabular}

\section{Hubungan nilai kuat tekan dan umur perawaan benda uji CPP}

Gambar 6 memperlihatkan hasil pengujian kuat tekan CPP dengan variasi umur 7, 14, 21, dan 28 hari perawatan untuk tiga jenis campuran A,B dan C dimana tiap variasi campuran terhadap umur perawatan mengalami kenaikan kuat tekan rerata masingmasing sebesar $11.32,7.17$ dan $4.15 \mathrm{~kg} / \mathrm{cm}^{2}$. Awal pengujian 7 hari pada campuran $\mathrm{A}$, 
B dan C memiliki kuat tekan masing-masing sebesar 117.79, 78.15 dan $64.56 \mathrm{~kg} / \mathrm{cm}^{2}$. Kemudian, material CPP terus mengalami peningkatan kuat tekan hingga maksimum pada umur 28 hari berturut-turut sebesar 151.77, 99.67 dan $77.02 \mathrm{~kg} / \mathrm{cm}^{2}$. Sebaliknya, kekuatan tekan tiap waktu perawatan 7 hingga 28 hari terhadap variasi campuran mengalami penurunan dari campuran A ke B dan dari B ke C rata-rata sebesar 46.72 dan $19.8277 .02 \mathrm{~kg} / \mathrm{cm}^{2}$. Berdasarkan nilai tersebut, material CPP dan CPB pada tingkat mutu bata beton untuk campuran A termasuk kedalam tingkat mutu I sedangkan untuk campuran B dan $\mathrm{C}$ termasuk kedalam mutu tingkat II.

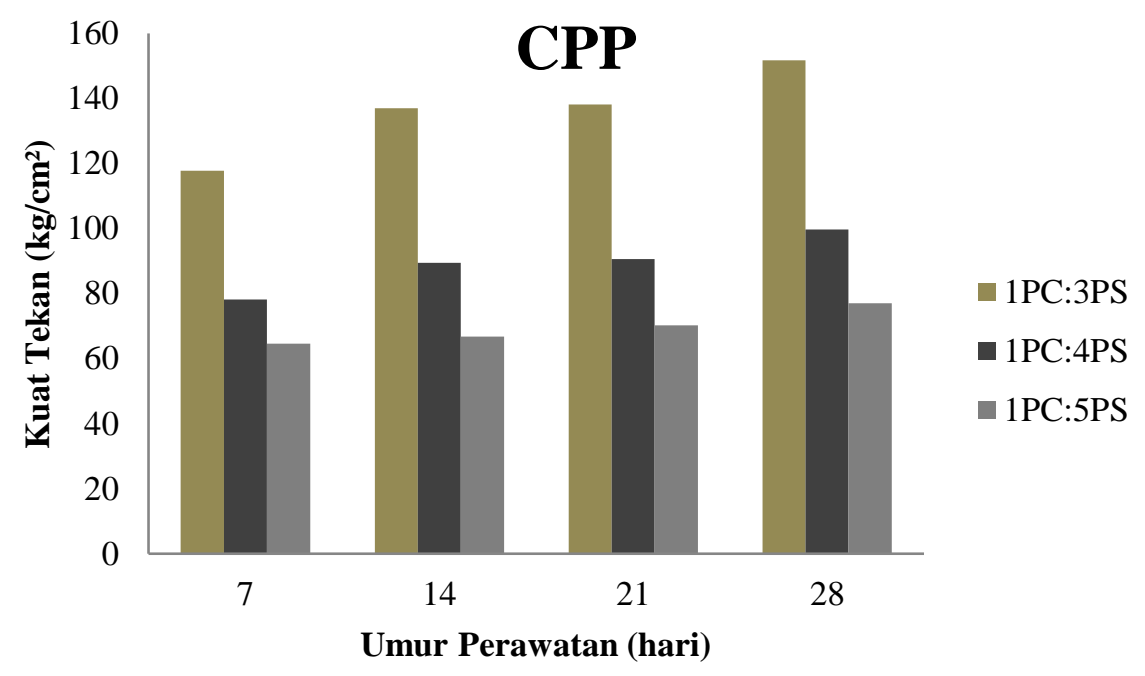

Gambar 6. Kuat Tekan Vs Umur Perawatan

\section{Hubungan nilai kuat tekan dan umur perawaan benda uji CPB}

Gambar 7 memperlihat perubahan kuat tekan benda uji CPB terhadap ketiga campuran $\mathrm{A}, \mathrm{B}$, dan $\mathrm{C}$ dan variasi umur perawatan dari 7 hingga maksimum 28 hari. peningkatan kuat tekan terjadi seiring umur perawatan namun mengalami penurunan kuat tekan terhadap penambahan rasio material PB dimana hal ini serupa dengan sifat kekuatan tekan material PP. Pada umur 7 hari perawatan terhadap tiga variasi campuran A,B dan C, besarnya nilai kuat tekan rata-rata sebesar 121.19, 80.42 dan $64.56 \mathrm{~kg} / \mathrm{cm}^{2}$. Nilai ini terus mengalami peningkatan untuk setiap variasi campuran hingga mencapai 28 hari berturut-turut sebesar 163.10, 100.8, $81.55 \mathrm{~kg} / \mathrm{cm}^{2}$. 


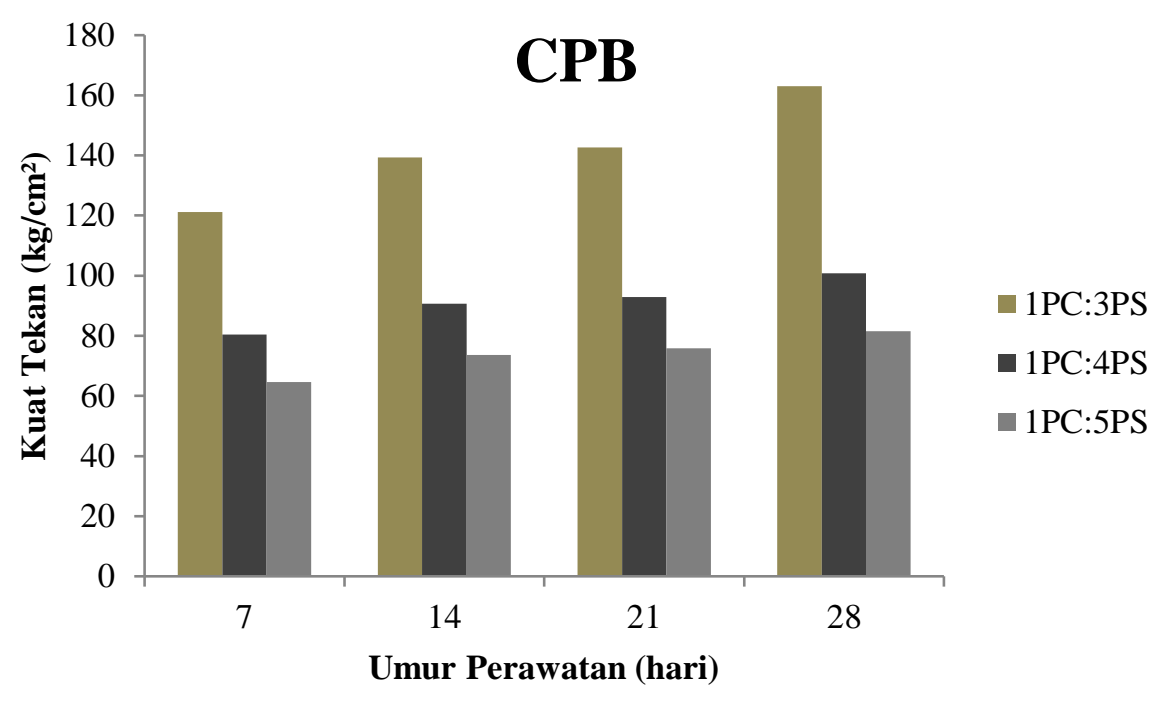

Gambar 7. Kuat Tekan Vs Umur Perawatan

Nilai korelasi R CPP dan CPB untuk variasi campuran $A$

\section{PC:3PS}

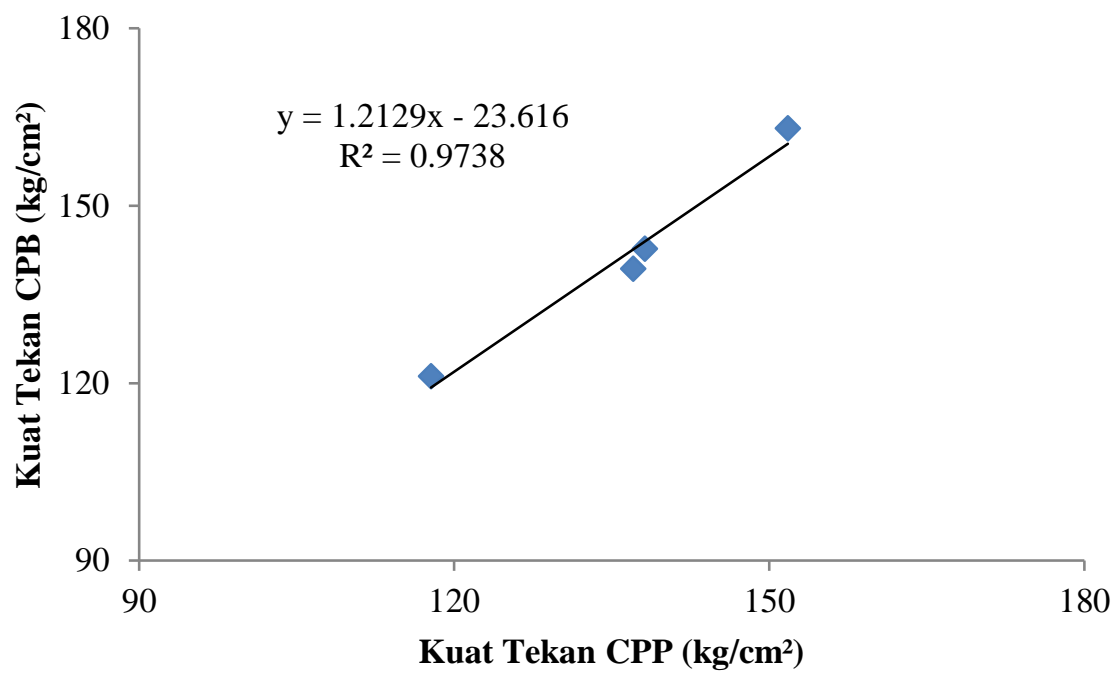

Gambar 8. Korelasi kuat tekan CPP dan CPB campuran A

Korelasi antara material CPP dan CPB untuk campuran A dapat dilihat pada Gambar 8. Berdasarkan hasil analisis yang dilakukan, maka hubungan kuat tekan antara kedua material menunjukkan nilai $\mathrm{R}^{2}=0.9738$. Nilai ini menggambarkan relasi antara kedua material sangat tinggi atau dengan kata lain bahwa hamper tidak memiliki perbedaan yang signikfikan terhadap kekuatan tekan kedua campuran. Korelasi ini dapat digambarkan dengan persamaan lininear dimana y adalah variable kuat tekan CPB dan x adalah variable kuat tekan CPP seperti terlihat pada pers. 2.

$y=1.2129 x-23.616$ 


\section{Nilai korelasi $R$ antara CPP dan CPB untuk variasi campuran B}

Gambar 9 memperlihatkan korelasi jenis campuran B antara spesimen CPP dan CPB ditinjau dari sisi kekuatan tekan masing-masing spesimen. Dari hasil analisis korelasi ini, nilai $\mathrm{R}^{2}=0.9966$ dengan hubungan persamaan linear keduanya seperti pada pers. 3 .

$y=0.9502 x+6.154$

Berdasarkan korelasi masing-masing nilai $\mathrm{CPP}$ dan $\mathrm{CPB}$ dapat diperlihatkan secara jelas bahwa nilai campuran 1PC:3PS memiliki korelasi tinggi dan kuat tekan tinggi dibandingkan dengan campuran 1PC:4PS.

\section{PC:4PS}

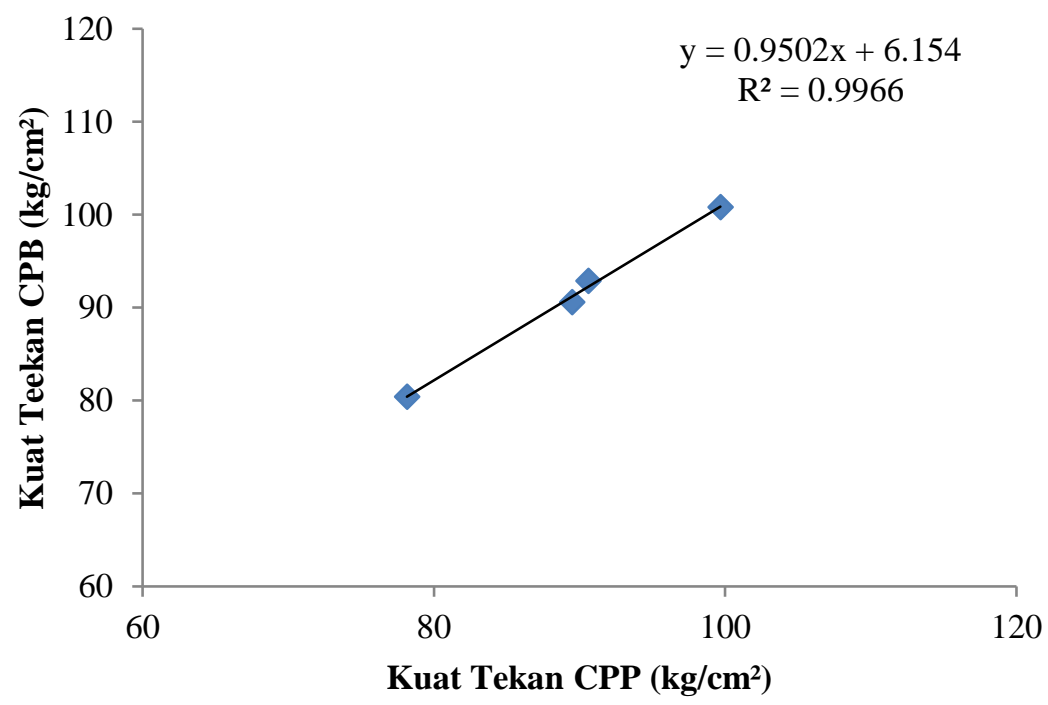

Gambar 9. Korelasi kuat tekan CPP dan CPB campuran B

\section{Nilai korelasi $R$ antara CPP dan CPB untuk variasi campuran $C$}

Dari Gambar 10, nilai korelasi yang diperlihat lebih kecil dibandingkan dengan campuran $\mathrm{B}$ dan $\mathrm{A}$ yang besarnya $\mathrm{R}^{2}=0.8451$. Hal ini berarti bahwa hubungan kuat tekan campuran 1PC:5PS belum ideal digunakan dalam konstruksi bata beton untuk digunakan pada konstruksi struktural dibandingkan dengan jenis campuran 1PC:3PS dan 1PC:4PS. 


\section{PC:5PS}

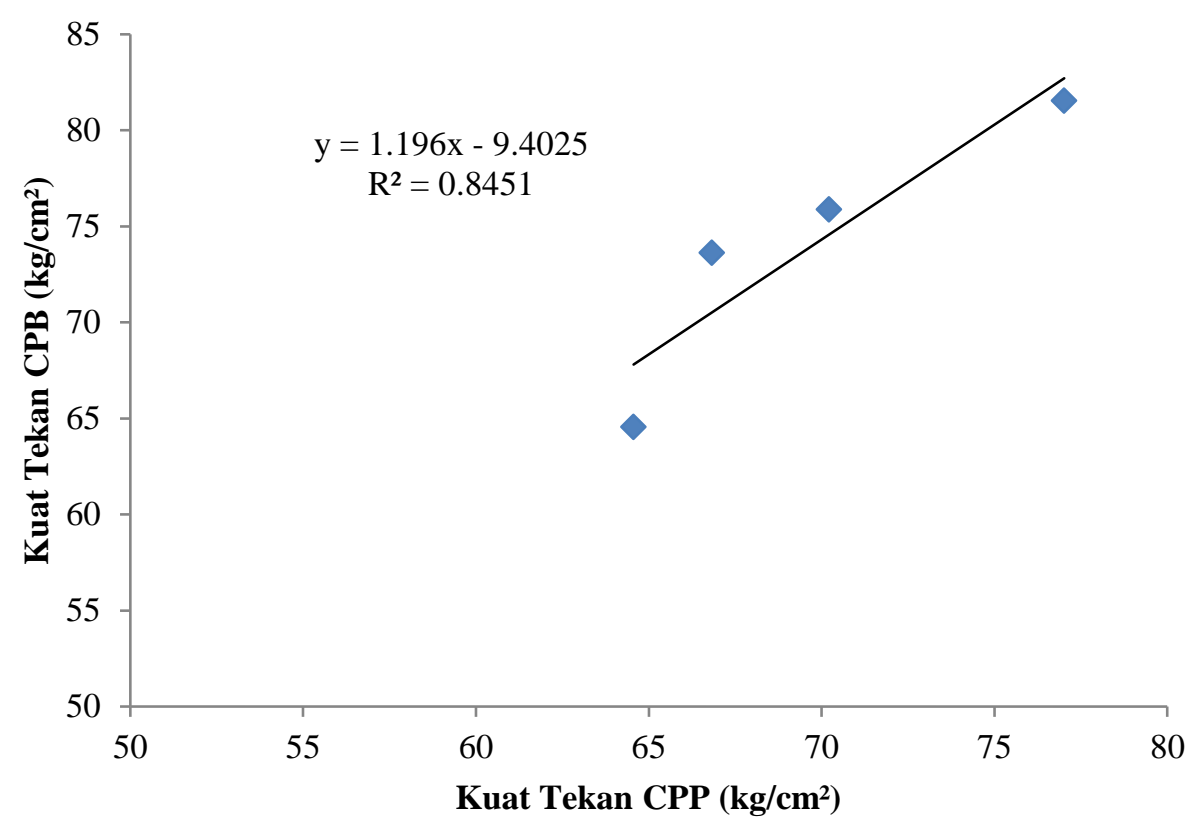

Gambar 10. Korelasi kuat tekan CPP dan CPB campuran C

\section{KESIMPULAN}

Dari hasil pengujian kuat tekan bata beton dengan menggunakan material pasir putih dan pasir biasa sungai masamba, penelitian ini memberikan beberapa kesimpulan:

a) Kuat tekan $\mathrm{CPP}$ lebih tinggi dari $\mathrm{CPB}$ untuk ke tiga variasi campuran $\mathrm{A}, \mathrm{B}$, dan C.

b) Tingkat mutu material CPP dan CPB untuk campuran A termasuk kedalam mutu tingkat I sedangkan untuk campuran B dan $\mathrm{C}$ termasuk kedalam mutu tingkat II.

c) Korelasi antara material $\mathrm{CPP}$ dan $\mathrm{CPB}$ menggambarkan relasi tertinggi untuk campuran A sebesar $\mathrm{R}^{2}=0.9738$.

\section{DAFTAR PUSTAKA}

Saniah, Purnawan, S., \& Karina, S. (2015). Karakteristik Dan Kandungan Mineral Pasir Pantai Lhok Mee, Beureunut Dan Leungah, Kabupaten Aceh Besar. DEPIK, 3(3). https://doi.org/10.13170/depik.3.3.2176

Alexander, M. \& Mindess, S., (2005). Aggregates in Concrete, Taylor \& Francis, New York.

Dyahwanti, I. N. (2007). Kajian Dampak Lingkungan Kegiatan Penabangan Pasir Pada Daerah Sabuk Hijau Gunung Sumbing Di Kabupaten Temanggung. Tesis, Universitas Diponegoro.

Li, Z. (2011). Advanced Concrete Technology. John Wiley and Sons, New Jersey, Kanada.

Maulana, I. (2012). Pengaruh Variasi Dolomit Material Lokal Kabupaten Bangkalan Sebagai Subtitusi Agregat Dalam Pembuatan Batako Terhadap Kuat Tekan Dan Absorpsi. Jurnal Sipil,1- 4. 
Silvia, L., Zainuri, M., Subagyo, B. A., Sukamto, H., \& Purwaningsih, S. Y. (2018). Analisis Kandungan Mineral Pasir Pantai di Kabupaten Pacitan dengan Metode Ekstraksi. Seminar Nasional Edusaintek, 16-20.

SNI 03-0349.(1989). Bata Beton untuk Pasangan Dinding. Badan Standardisasi Nasional.

Yudhistira, Y., Hidayat, W. K., \& Hadiyarto, A. (2012). Kajian Dampak Kerusakan Lingkungan Akibat Kegiatan Penambangan Pasir Di Desa Keningar Daerah Kawasan Gunung Merapi. Jurnal Ilmu Lingkungan, 9(2), 76. https://doi.org/10.14710/jil.9.2.76-84 